\title{
人工関節の摩耗特性に及ぼす酸素濃度の影響
}

\author{
星野了太 \\ 九州産業大学工学部
}

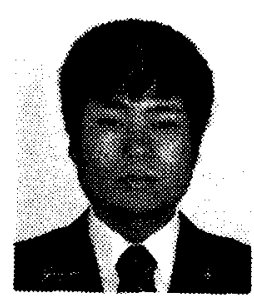

1.はじめに

金属摺動面はその最表層より，吸着分子層一金属酸化 膜層一加工変質層一金属素地のように微視的な階層構造 1) を有している. 摺動面の摩耗は複雑であり，化学的腐食と物 理的損傷のいずれをも含んでいる. 摩耗過程の一つに凝着 摩耗がある.これは2つの摺動面間の微視的・局所的な凝着 とそのせん断により発生 ${ }^{2)}$ する. 一般的に金属酸化膜は2面 間の凝着を抑制し摩耗の减少をもたら'すと考えられている. ゆえに，酸素丧度を低下させると糜耗過程で破壊された酸化 膜が十分に修復できないため凝着が增大する. その結果, 摩擦·摩耗が増加すると考えられている. 生体内の酸素浱度 は大気中の $1 / 5 \sim 1 / 3$ と低いため, 金属同士が接触し, 摩察 するMetal-on-Metal 人工股関節でも, 酸素浱度低下による 摩耗増加現象が発生する可能性がある。

そこで本研究では，同一金属同士の摩耗特性が酸素濃度 の低下によりどのように変化するかを調查した。

\section{2. 实䟻方法}

試験装置の概略を図1に示す. 実験では pin·on-plate 摩 耗試験機を使用した. 表 1 に実験条件を示す. 試験材料は $\mathrm{Co}-28 \mathrm{Cr}-6 \mathrm{Mo}$ 合金亡機械構造用炭素龬 S45C とした.これ をピンとプレートに加工し，同じ材料同士を摩擦した. プレー 卜を一方向に回転させ, 滑り速度を $30.0 \mathrm{~mm} / \mathrm{s}$, 摩擦円半径を $15.0 \mathrm{~mm}$ とした. 接触面圧を $2.0 \mathrm{MPa}$ とした. 試験中の潤滑状 热は無潤滑(乾燥摩擦;Dry) または水系潤滑とした. 水系潤 滑での润滑液には, リン酸緩衝生理食塩液(Phosphate buffered saline; PBS) または PBSにヒト血清由来蛋白等を 溶解させた模㩆関節液(Simulated synovial fluid) 光を使用

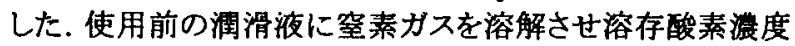
を低下させた. 装置を密閉容器内に設置し, 窒素ガスを注入 することにより㞣囲気中の酸素濃度を制御した．設定值は $20.9 \%$ (大気中) , $10.0 \%, 5.0 \%, 0.1 \%$ とした. 各酸素濃度と も 3 回ずつ試験を行った. 試験中の摩擦係数の推移を計測 し, 平均摩擦俰数を求めた. 各試験条件で設定した摩擦距 離に達した時点で, ピンとプレートの摩耗重量を測定した。

Table 1 Test condition

\begin{tabular}{|l|ll|}
\hline Test material & Co-28Cr-6Mo, S45C & \\
Sliding speed & $30.0 \mathrm{~mm} / \mathrm{s}$ & \\
Radius of wear trak & $15.0 \mathrm{~mm}$ & \\
Contact pressure & $2.0 \mathrm{MPa}$ & $1.0 \times 10^{2} \mathrm{~m}$ \\
& Dry : & $5.0 \times 10^{3} \mathrm{~m}$ \\
Lubricating condition & Phosphate buffered saline: & $5.0 \times 10^{3} \mathrm{~m}$ \\
and sliding distance & Simulated synovial fluid: & $5.0 \times 1$ \\
\hline
\end{tabular}

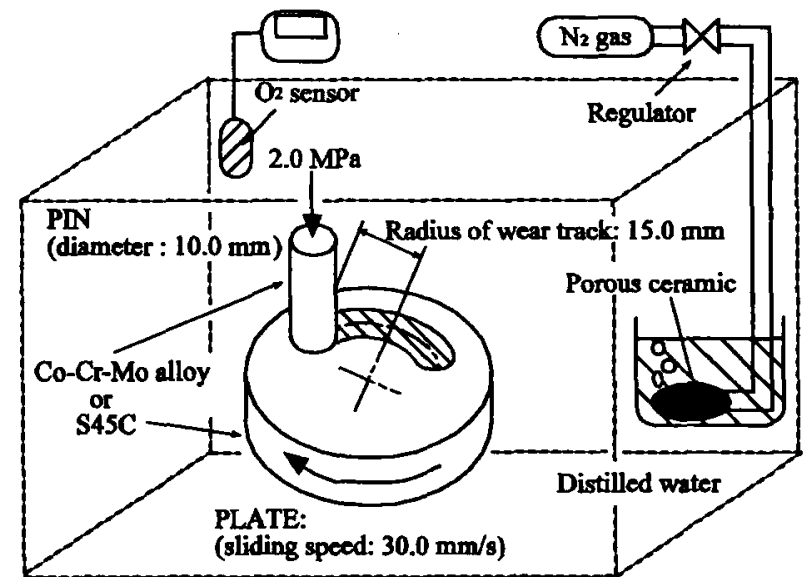

Fig. 1 Schematic representation of the pin-on-plate wear tester.

\section{3. 结果および考察}

\section{1. 糜徖特性に与える酸素漬度の影望}

平均摩擦係数を润滑状態で分類したグラフを图 2に示す。 S45C 同士を摩擦した実験では，潤滑条件が乾燥摩擦から PBS 潤滑，模擬関節液潤滑に变更されるにつれて摩擦倸数 が低下することが観察され，摩擦状態が緩和されたことが示 された. Co-Cr-Mo 合金同士を模擬関節液で潤滑した条件 では，酸素浱度の低下にともない摩察係数が减少する傾向 が観察されたが，その他の条件では酸素浱度の低下にともな い摩擦係数がやや増加する傾向も観察された. しかしながら, 全体的には酸素浱度の低下が摩擦特性に与える影警は小さ かった.

\section{2. 摩耗特性に与える酸素灌度の影霜}

ピンとプレートそれぞれの平均糜耗量を, 大気中(20.9\%)を 基準とした低酸素浱度での変化率で表したグラフを図 3 に示 す.乾燥摩擦では,ピンの摩耗量は 0.1\%でやや低值を示す

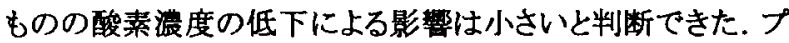
レートの摩耗量では, 酸素灙度の低下にともない摩耗が增加 する傾向が観察された. ピンとプレートの総摩耗量では, 酸 素漶度の低下にともない摩耗が増加する傾向を示した. この ことから, 酸素浱度の低下が局所的凝着を增大させ, 高摩擦 と高摩耗を発生させたと考えられる.この現象は，一般的な 凝着摩耗説(低酸素浱度が高摩擦と高摩耗をもたらす)で説 明可能な現象であった. ピンとプレートで摩耗特性が異なる のは, 2 つの摺動面に摩徖の過酷さの差 ${ }^{4}$ があるためと思わ 
れる. 同じ酸素濃度でも過酷さが異なれば, 酸素の供給量が 変化するため, 新生面(金属酸化膜が破壊され露出した金属 素地)の修復速度などが変化し, 金属材料の特性がその場で 変化することが考えられる. ピンの場合は, 摺動面がプレート 側と常時接触しているため酸素の供給が妨げられ, 酸素濃 度の影響が小さかったと考えられる. プレートの場合は, 摺動 面がピンにより常時被覆されてないため酸素が供給され，摩 擦により損傷を受けた金属酸化膜が再修復しやすいと考えら れる. そのため, 酸素濃度の変化が金属酸化膜の再修復過 程に影響を与えていると考えられる.

水系潤滑では, ピンとプレートの摩耗量はすべての試験条 件で酸素濃度の低下にともない摩耗が減少する傾向が観察 された.この現象は凝着摩耗説で説明できない現象であった. 同じ潤滑状態でもピンとプレートで摩耗特性が異なる例が観 察されたことから, 水系潤滑においてもピンとプレートで摩擦 の過酷さの差 ${ }^{4)}$ にり, 摩耗特性が変化すると考えられる.

\section{4. まとめおよび今後の展望}

同一金属同士の摩耗特性が酸素濃度の低下によりどのよ うに変化するかを調査した. その結果, 乾燥摩擦では酸素濃 度の低下により摩耗が増加する傾向が観察され, 凝着摩耗 説で説明できることが確認できた.しかし，水系潤滑ではす べての試験条件において, 酸素濃度の低下により摩耗が減 少する傾向が観察され，特定の材料や潤滑液に限定されず 凝着摩耗説で説明できないことが明らかとなった。

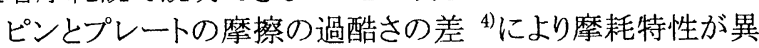
なることが明らかとなった.この現象は, 人工股関節の摺動面 形状を変更した際にも起こりらる現象 5)であると思われるため, 今後の人工股関節の設計に役立てたい.

摩耗過程には凝着摩耗の他に切削摩耗がある. 今後, 切 削摩耗を対象とした実験などを行い, 凝着摩耗説に従わな い現象が発現するメカニズムを解明したい。
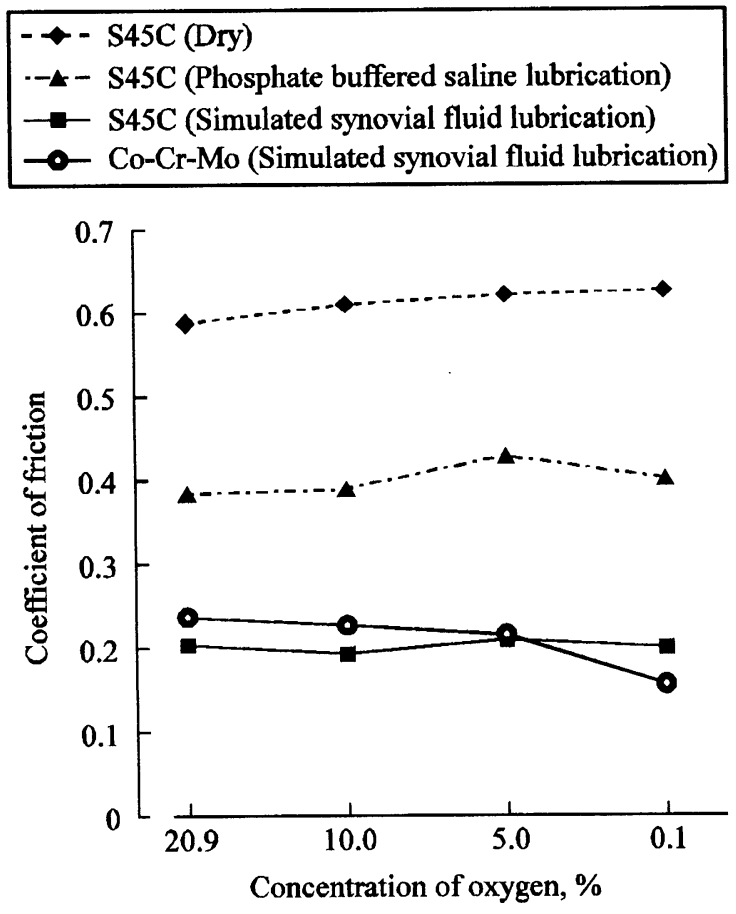

Fig. 2 Influence of oxygen concentration on coefficient of friction.
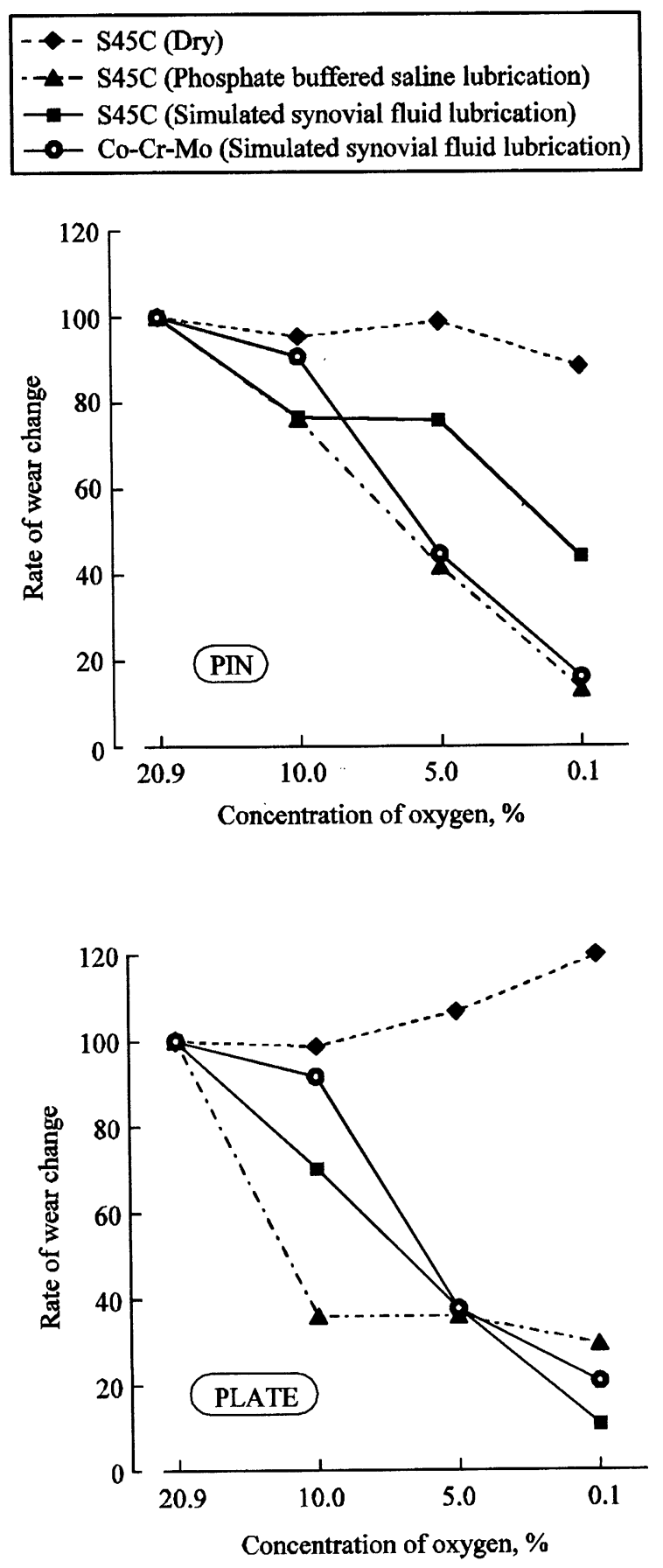

Fig. 3 Influence of oxygen concentration on wear.

\section{5. 参考文献}

1）山本・兼田,トライボロジー, 理工学社, 1998.

2) Bowden,F.P. and Taber,D., Friction and Lubrication of Solids, Oxford, 1954.

3) 中西・他 4 名, 日本臨床バイオメカニクス学会誌 25 , 2004,pp.389-393.

4）中西・他 5 名,日本臨床バイオメカニクス学会誌 20 , 1999,pp.287-292.

5) Masuda,T. et al., Proc.14th Int.Colloquim Tribology,3, 2004, pp.1745•1749. 